\title{
DIAGNOSIS OF WATER TRANSPORT SAFETY STATE AND SYSTEM
}

\section{DIAGNOZA STANU I SYSTEMU BEZPIECZEŃSTWA TRANSPORTU WODNEGO}

\author{
Hajduk Jerzy \\ Maritime University of Szczecin \\ Akademia Morska w Szczecinie \\ 70-500 Szczecin, Wały Chrobrego $1 / 2$ \\ e-mail: jhaj@am.szczecin.pl
}

\begin{abstract}
The diagnosis of water transport safety concerns marine transport conducted in Polish marine areas and inland fairways. Marine shipping is subject to safety regulations of the International Maritime Organisation, the European Union and domestic regulations. Its specificity concerns mainly transit traffic in the Baltic Sea, where the traffic is not supervised, and the effects of a sea disaster may be felt in the Polish coast.
\end{abstract}

Key words: water transport, safety of navigation

Streszczenie: Diagnoza bezpieczeństwa transportu wodnego dotyczy transportu morskiego prowadzonego na polskich obszarach morskich i transportu śródlądowego prowadzonego na śródlądowych drogach wodnych. Żegluga morska podlega przepisom bezpieczeństwa Międzynarodowej Organizacji Morskiej, Unii Europejskiej i krajowym. Jej specyfika dotyczy w dużej mierze ruchu tranzytowego na Morzu Bałtyckim, gdzie ruch nie jest nadzorowany, a skutki katastrofy morskiej mogą być odczuwalne na wybrzeżu polskim.

Slowa kluczowe: transport wodny, bezpieczeństwo żeglugi 


\section{DIAGNOSIS OF WATER TRANSPORT SAFETY STATE AND SYSTEM}

\section{Introduction}

With regard to safety, marine transport is characterised by its specificity. In the Baltic Sea vessel traffic is relatively highly intense with a small number of accidents. Depending on the effects, marine accidents are characterised by an extremely high number of casualties in the case of passenger ship disasters or large threat to the environment in the case of vessels carrying dangerous cargo. For example, there were in total 989 persons on the ferry Estonia, which sank in the Baltic in 1994, out of which 138 were saved. Next, in 199355 persons lost their lives in the disaster of ferry Jan Heweliusz off the coasts of Rugia (Rügen) island, 9 persons being saved.

Fortunately, there has been no ecological disaster in the Baltic Sea yet, although it must be borne in mind that a lot of tankers with a maximum draft of 15.5 metres sail in this sea every day, and the loaded tanker Prestige in 2002, before it broke down off the coast of Spain, had previously sailed the Baltic on the route from the Gulf of Finland (Russia) to the Danish Straits. The essence of safety at sea is preventive activity carried out by coastal states (designating shipping routes, monitoring vessel traffic, port state inspections verifying the technical condition of vessels) and establishing strict regulations on international level concerning the principles of vessel construction and equipment.

The scope of supervision over safety at sea results from the Act on Marine Areas of the Polish Republic and Marine Administration of $21^{\text {st }}$ March 1991 with later amendments. The system of managing marine areas in Poland is based on three Marine Boards, which have shipping safety supervision services in their structures.

The problem of marine rescue system functioning is regulated in Poland by numerous national regulations and international conventions, the Republic of Poland being a party of them.

Transport on inland water routes is currently conducted in a limited range in Poland. 


\section{Water areas}

On the basis of the Act Concerning the Maritime Areas of the Republic of Poland and the Maritime Administration of $21^{\text {st }}$ March 1991, the maritime areas of the Republic of Poland are:

- the inland waters;

- the territorial area;

- the exclusive economic zone,

hereinafter referred to as "Polish maritime areas". (Fig.1). The internal waters and the territorial sea are part of the territory of the Polish Republic. The exclusive economic zone, on the other hand, is defined in the context of supervising and using natural resources and other economic activity.

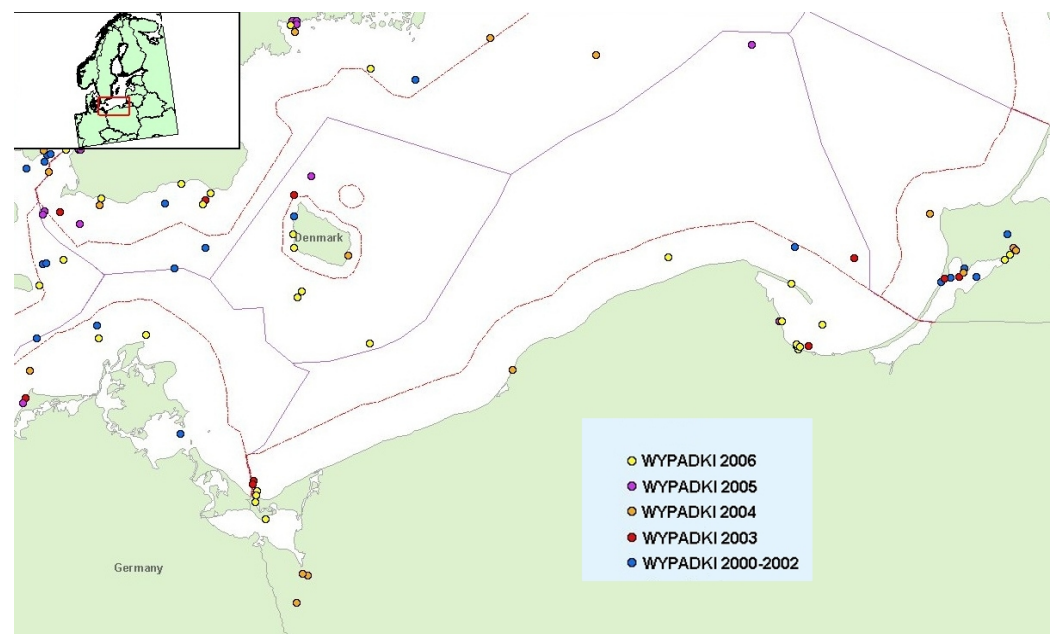

Fig. 1. The Southern Baltic Area with Polish maritime areas.

The total length of inland waterways considered navigable equalled 3638,0 $\mathrm{km}$ in Poland in 2005, out of which about $3323,0 \mathrm{~km}$ were actually operated by cargo and passenger shipping [2]. Yet in actual fact it is only through the river Odra (Oder) joining the Oder-Havel Canal and Oder-Spree Canal that the country's waterway network has a navigationally operated connection with the German and West-European waterway network. The multivariant East-West waterway running through Polish territory exists only in theory, linking the German waterway network with shipping routes of Russia, White Russia and the Ukraine [1]. 


\section{Vessel traffic}

Vessel traffic at sea is generally disordered. The criterion for selecting the shortest route to the point of destination is conditioned by available depths and state of the weather. In the face of increasing vessel traffic intensity on approaches to ports and in places of natural traffic condensation (straits, capes) traffic separation schemes are established. On numerous water areas shipping routes are also applied without a defined width or traffic separation zones. It may be assumed that on relatively very small water areas the vessel traffic is ordered, whereas on the decisive majority of them - accidental (chaotic) traffic - Fig.2 [1].

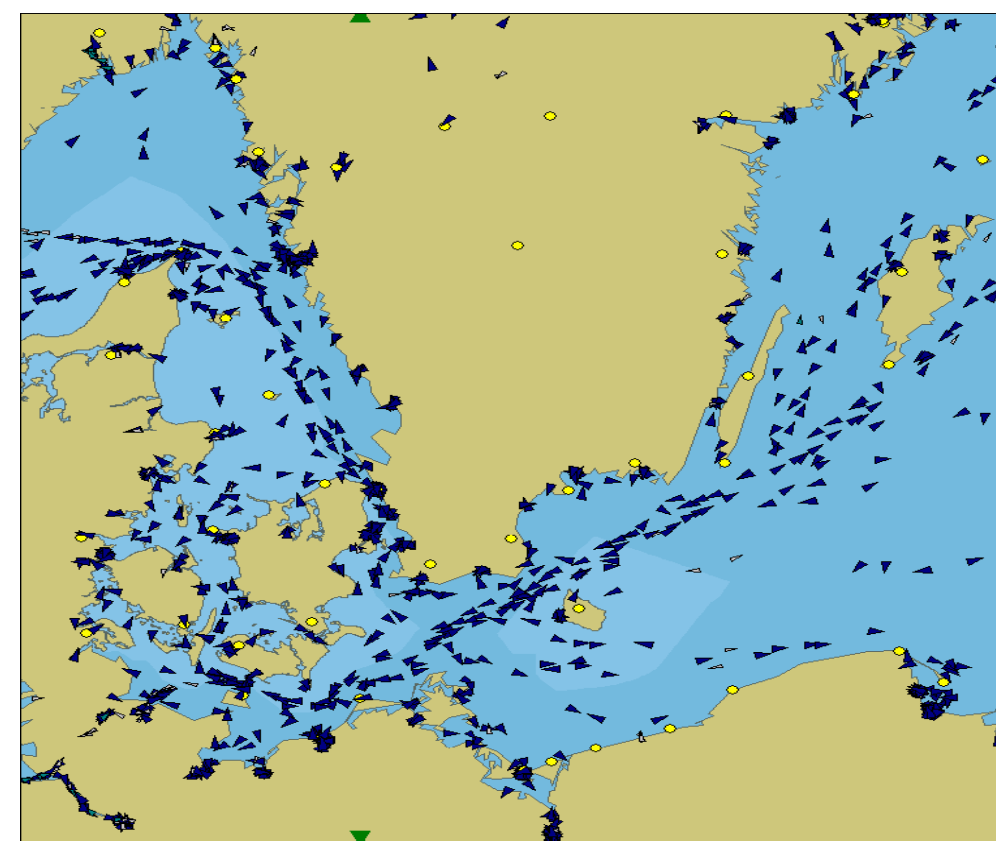

Fig. 2. Vessel traffic in the Western Baltic

\section{Accidents}

Based on the Helsinki Commission data, 23 marine accidents took place in Polish maritime areas in the years $2004-2007$. This applies to both events in the open sea and in port water areas. According to these data, the human factor was the most frequent accident cause $-66 \%$, the next group of factors being technical breakdown and external factors - 13\%. (Fig.3). 


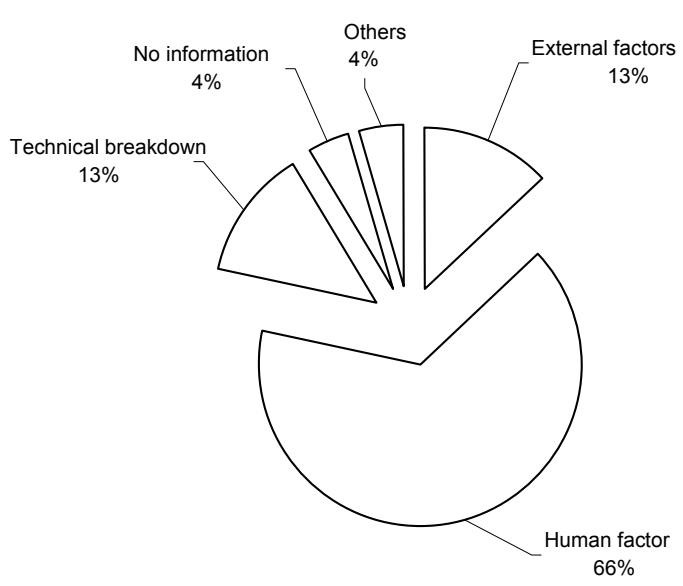

Total marine accidents -23

Fig. 3. Causes of marine accidents in the Baltic Sea in Polish maritime areas in the years 2004 - 2007 [Study based on HELCOM 2004 - 2006]

In Fig. 4, the place of accident and vessel types breaking down have been juxtaposed. According to these data, most marine accidents were in ports and in roads, next in open areas and straits, canals and rivers.

Cargo vessels break down most frequently, including tankers. The group of bulk carriers is distinctive in a negative way. The age of the vessels is an essential factor; there is a clear upward trend for vessels more than 15 years old.

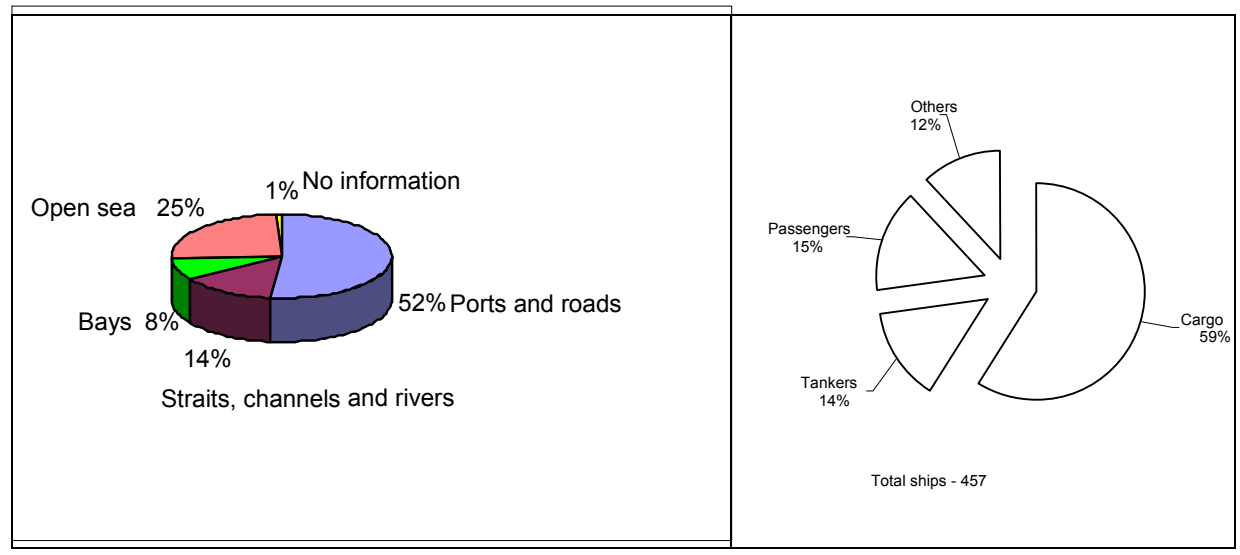

Fig. 4. Incidence of navigational accidents in the years 2000-2006 
22 accidents in inland transport were officially recorded in 5 inland shipping offices in the analysed period of 6 years [1].

\section{The staff}

The training of marine staff in Poland is systemically solved in accordance with the world's requirements and trends. There are two training centres of commercial fleet marine staff on university level and four main marine staff training centres on secondary school level.

Apart from higher and secondary education it is possible in Poland, in accordance with international standards, to train seagoing vessel crew members in courses for appropriate responsibility levels, which may be organised by training centres conducting economic activity, recognised by local organs of marine administration.

The basic staff directly employed on inland vessels is made up of Inland Shipping Secondary Technical Schools graduates. In spite of some reduction of this type of schools due to regression of carriages and property changes taking place, currently three secondary schools are functioning, training staff for this type of shipping (Nakło, Kędzierzyn-Koźle, Wrocław). They are supplemented by Marine Technical Schools at Szczecin, Gdynia, Kołobrzeg and Świnoujście, enabling the graduates to obtain diplomas of marine navigator and ship engineer [1].

\section{Safety systems}

For the whole of marine administration PHICS (Polish Harbours Information \& Control System) system has been created from scratch, that is, the electronic exchange of documents essential for performing the duties imposed on the port state administration and the coastal state. The system was designed and implemented by the firm Grupa Emax and has been functioning since $11^{\text {th }}$ May 2004. The system user is the Ministry of Marine Economy, marine boards, SAR, and also Customs Service and the Border Guard (Fig.5).

In Poland marine accidents are investigated by marine chambers which are legal institutions, whereas there are no institutions to carry out monitoring and analysing of marine accidents from the navigational safety point of view. 


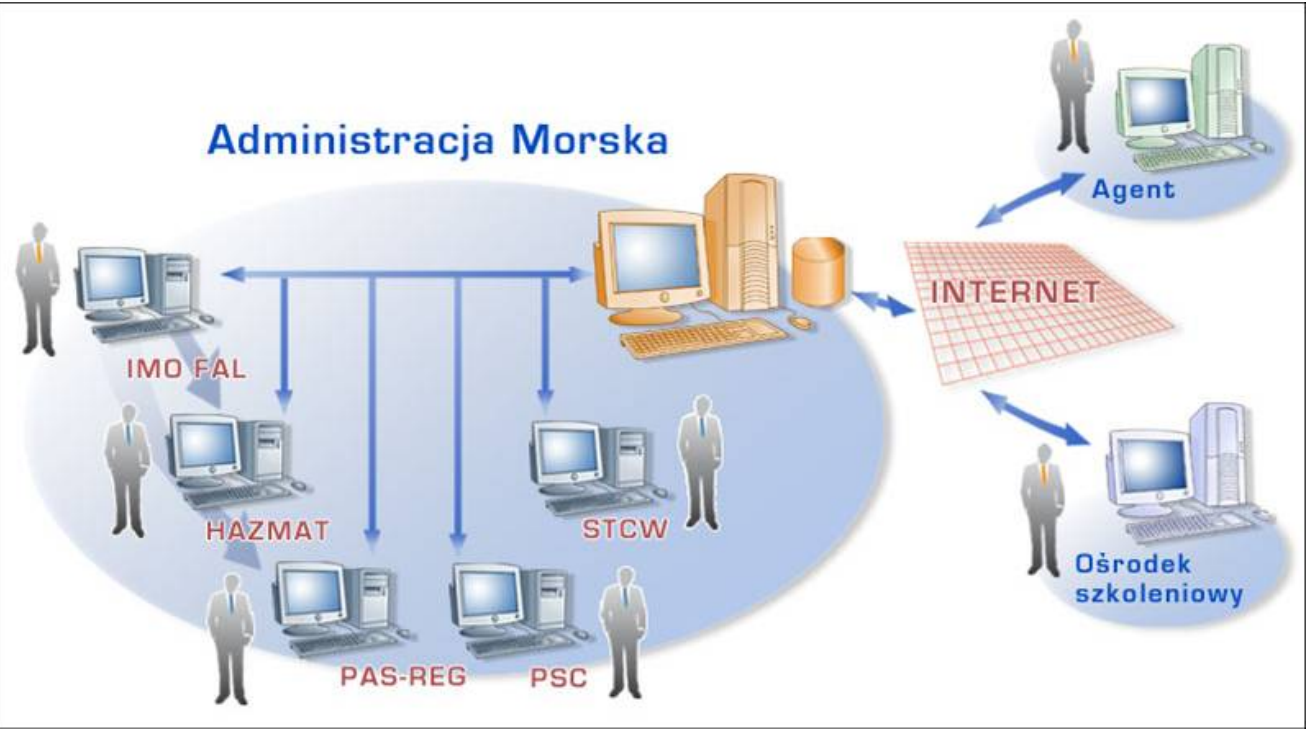

Fig. 5. Logical flow-chart of PHICS system

VTS systems function at the Marine Boards at Szczecin and Gdynia, and the Marine Administration Headquarters of Ustka at the Marine Board of Słupsk.

For performing the tasks of search and rescue at sea the SAR service has specialist rescue vessels and coastal rescue vessels equipped with allterrains vehicles (ATV) and fast rescue boats (FRB).

In the range of improving supervision over navigational safety it is planned to set up a National System of Marine Safety (Polish acronym KSBM). This system is being built on the basis of existing, largely modernised infrastructure. The chief aim of the system built is the improvement of marine navigational safety and counteracting the contamination of marine environment in maritime areas of the Republic of Poland. The main tasks of the KSBM system boil down to creating and maintaining conditions indispensable for safe and effective human activity in the Polish Republic's maritime areas and ensuring that shipping or any other activity at sea is performed in accordance with current Polish law regulations and international agreements [1]. 


\section{Recapitulation}

Marine transport safety is specific. In Polish maritime areas, apart from port approach zones vessel traffic is uncoordinated. Transit traffic in the open sea generates potentially dangerous situations, requiring the conduct of rescue actions, and the effects of possible sea disasters may pose a menace to the Polish coast. Inland waterways, on the other hand are very poorly used for transport functions.

Marine accidents in the Baltic Sea happen relatively rarely; each sea disaster, however, may cause large material losses and totally irreversible ecological effects.

The majority of accidents at sea are caused by human factor. The training of marine staff in Poland is systemically well-designed; paradoxically, however, marine transport safety in Polish maritime areas largely depends on staffs trained in other, sometimes very distant nooks of the world.

Currently introduced technical solutions make it possible to manage safety on extensive water areas. In Poland, attempts are made to build such systems aimed chiefly at the improvement of marine navigation safety and counteracting the contamination of marine environment in the maritime areas of the Republic of Poland.

\section{Literature}

1. Diagnoza stanu systemu bezpieczeństwa transportu wodnego w Polsce identyfikacja słabych stron i zagrożeń. Zadanie 1.2. ZEUS. INTEGROWANY SYSTEM BEZPIECZEŃSTWA TRANSPORTU. Projekt zamawiany MNiSW. Sprawozdanie z badań. Akademia Morska w Szczecinie 2007.

2. Transport - wyniki działalności w 2005r. Główny Urząd Statystyczny. Warszawa 2006. 


\section{DIAGNOZA STANU I SYSTEMU BEZPIECZEŃSTWA TRANSPORTU WODNEGO}

\section{Wprowadzenie}

Transport morski w kontekście bezpieczeństwa charakteryzuje się swoją specyfiką. Na Morzu Bałtyckim istnieje stosunkowo duże natężenie ruchu statków przy występującej niewielkiej liczbie wypadków. Wypadki morskie w zależności od skutków charakteryzują się ekstremalnie dużą liczbą ofiar w przypadku katastrof statków pasażerskich lub dużym zagrożeniem dla środowiska w przypadku statków przewożących ładunki niebezpieczne. Przykładowo na promie m/f Estonia, który zatonął na Bałtyku w 1994 roku było w sumie 989 osób, z czego uratowano 138. Z kolei w roku $1993 \mathrm{w}$ katastrofie promu m/f Jan Heweliusz u wybrzeży Wyspy Rugia zginęło 55, a uratowano 9 osób.

Szczęśliwie do tej pory na Morzu Bałtyckim nie wydarzyła się katastrofa ekologiczna, jakkolwiek należy pamiętać, że po morzu tym pływa codziennie wiele zbiornikowców o maksymalnym dopuszczalnym zanurzeniu 15,5 metra, a załadowany zbiornikowiec Prestige w roku 2002 zanim uległ awarii na wysokości wybrzeża Hiszpanii wcześniej przepływał przez Bałtyk na trasie Zatoka Fińska (Rosja)-Cieśniny Duńskie.

Istotą bezpieczeństwa na morzu jest działalność prewencyjna objawiająca się działaniami państw nadbrzeżnych (wyznaczanie tras żeglugowych, monitoring ruchu statków, inspekcje państwa portu weryfikujące stan techniczny statków) oraz ustalaniem na poziomie międzynarodowym przepisów regulujących zasady konstrukcji statków i ich wyposażenia.

Zakres nadzoru nad bezpieczeństwem na morzu wynika z Ustawy o obszarach morskich Rzeczypospolitej Polskiej i administracji morskiej z 21 marca 1991 wraz z późniejszymi zmianami. System administrowania obszarami morskimi w Polsce opiera się na trzech urzędach morskich, które w swoich strukturach posiadają służby nadzoru nad bezpieczeństwem żeglugi.

Problem działania systemu ratownictwa morskiego uregulowany jest $\mathrm{w}$ Polsce na podstawie licznych przepisów narodowych oraz konwencji międzynarodowych, których stroną jest Rzeczpospolita Polska.

Transport po śródlądowych drogach wodnych jest obecnie w Polsce prowadzony w bardzo ograniczonym zakresie. 


\section{Akweny wodne}

$\mathrm{Na}$ podstawie Ustawy $\mathrm{z}$ dnia 21.03.1991 o obszarach morskich Rzeczypospolitej Polskiej i administracji morskiej - obszarami morskimi Rzeczypospolitej Polskiej są:

a. morskie wody wewnętrzne,

b. morze terytorialne,

c. wyłączna strefa ekonomiczna,

zwane dalej "polskimi obszarami morskimi" \{rys.1). Morskie wody wewnętrzne $i$ morze terytorialne wchodzą $w$ skład terytorium Rzeczypospolitej Polskiej. Natomiast wyłączna strefa ekonomiczna jest definiowana $\mathrm{w}$ kontekście nadzoru i eksploatacji bogactw naturalnych $\mathrm{i}$ innej działalności ekonomicznej.

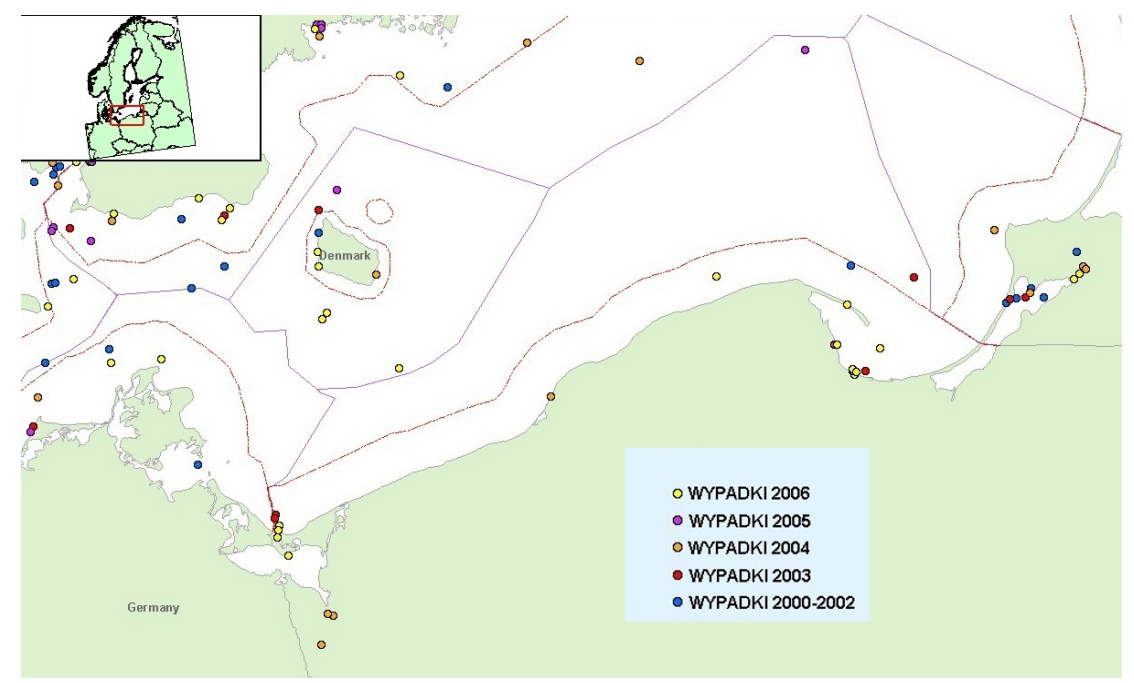

Rys. 1. The Southern Baltic Area with Polish maritime areas.

Całkowita długość śródlądowych dróg wodnych uznanych za żeglowne w 2005r. wynosiła w Polsce $3638,0 \mathrm{~km}$, z tego faktycznie eksploatowanych przez żeglugę towarową i pasażerską było około $3323,0 \mathrm{~km}$. [2]. Jednak w praktyce jedynie poprzez rzekę Odrę, łączącą się z kanałami Odra-Hawela i Odra-Szprewa, krajowa sieć dróg wodnych posiada eksploatowane żeglugowo połączenie $\mathrm{z}$ niemiecką oraz zachodnioeuropejską siecią dróg wodnych. Przebiegająca przez terytorium Polski kilkuwariantowa droga wodna Wschód-Zachód istnieje tylko teoretycznie, łącząc niemiecką sieć dróg wodnych ze szlakami żeglugowymi Rosji, Białorusi i Ukrainy [1]. 


\section{Ruch statków}

Ruch jednostek pływających na morzu jest generalnie nieuporządkowany. Kryterium wyboru najkrótszej drogi do punktu przeznaczenia warunkowane jest dostępnymi głębokościami i stanem pogody. Wobec zwiększającego się natężenia ruchu statków na podejściach do portów i w miejscach naturalnego zagęszczenia ruchu (cieśniny, przylądki) wystawiane są systemy rozgraniczenia ruchu. $\mathrm{Na}$ wielu akwenach stosuje się też trasy żeglugowe, które nie mają określonej szerokości i stref rozgraniczenia ruchu. Można przyjać, że na stosunkowo bardzo małych obszarach wodnych występuje uporządkowany statków, a na zdecydowanej większości ruch przypadkowy (chaotyczny)- rys.2 [1].

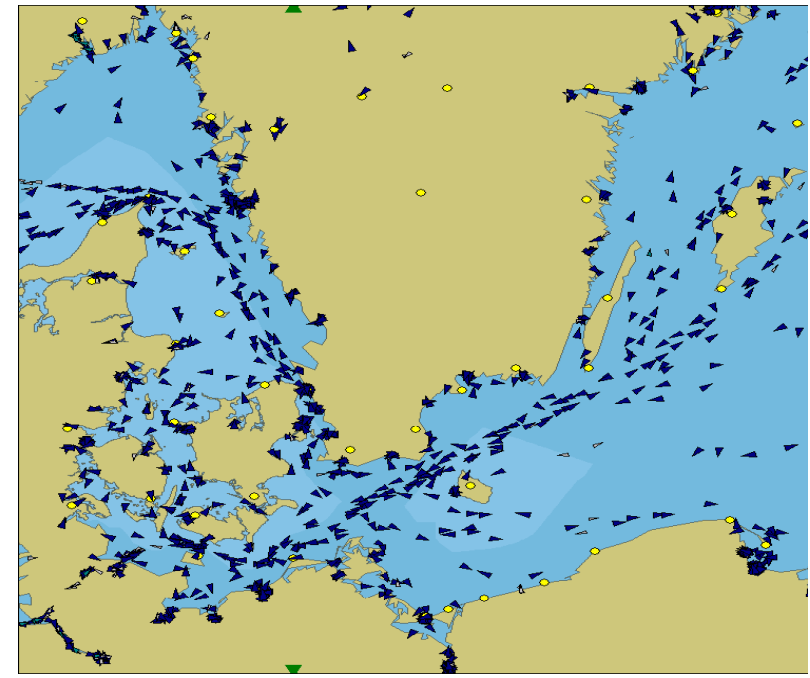

Rys. 2. Vessel traffic in the Western Baltic.

\section{Wypadki}

Na podstawie danych Komisji Helsińskiej, w latach 2004 - 2007 na polskich obszarach morskich miały miejsce 23 wypadki morskie. Wypadki te dotyczą zarówno zdarzeń na otwartym morzu jak i na akwenach portowych. Na podstawie tych danych, najczęstszą przyczyną wypadków był czynnik ludzki - 66\%, następną grupę czynników stanowiły awaria techniczna i czynniki zewnętrzne - po 13\%.(rys.3) 


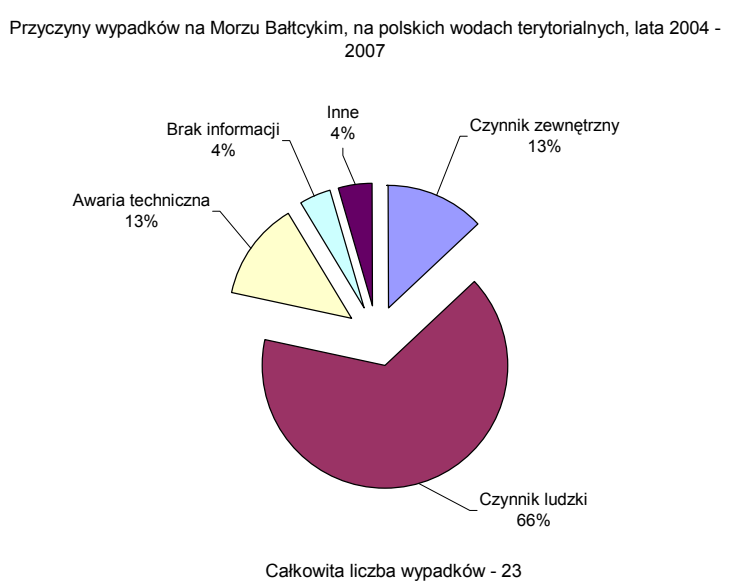

Rys. 3. Incidence of navigational accidents in the years 2004-2007.

Na rysunku 4 zestawiono miejsce występowania wypadków i typy statków ulegających awariom. Według tych danych najwięcej wypadków morskich było $\mathrm{w}$ portach $\mathrm{i}$ na redach, następnie na akwenach otwartych oraz $\mathrm{w}$ cieśninach, kanałach i na rzekach.

Najcześsiej awariom ulegają statki towarowe w tym zbiornikowce. Wyróżniającą się negatywnie jest grupa masowców. Istotnym czynnikiem jest wiek statków. Wyraźna tendencja zwyżkowa występuje dla statków o wieku powyżej 15 lat.

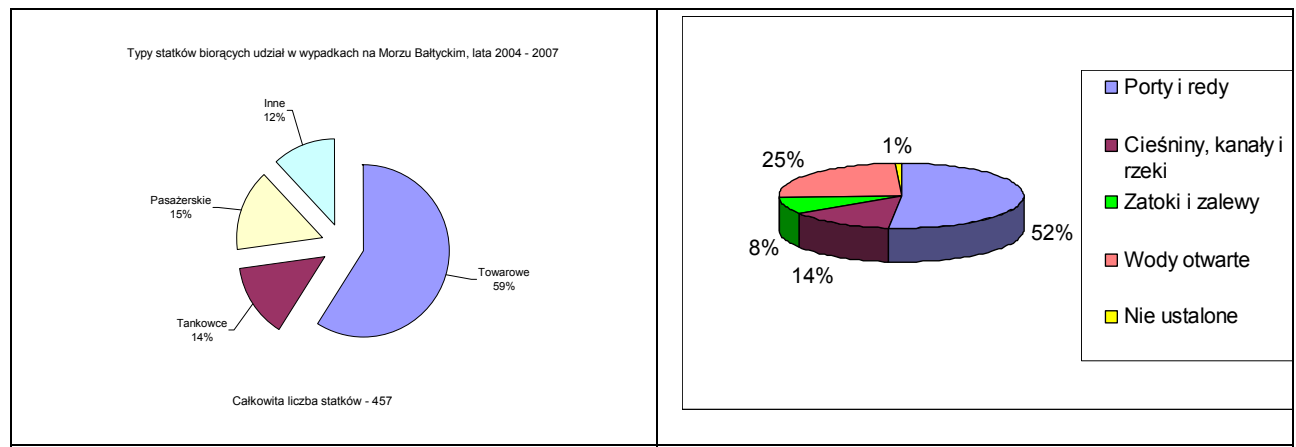

Rys. 4. Incidence of navigational accidents in the years 2000-2006.

W transporcie śródlądowym $\mathrm{w}$ analizowanym okresie 6 lat oficjalnie w 5 urzędach żeglugi śródlądowe odnotowano 22 wypadki [1].

\section{Kadra}

W Polsce systemowo kształcenie kadr morskich jest rozwiązane zgodnie $\mathrm{z}$ wymaganiami i trendami światowymi. Istnieją dwa ośrodki szkoleniowe 
szkolące kadrę morską floty handlowej na poziomie szkoły wyższej oraz cztery główne ośrodki szkoleniowe kadry morskiej na poziomie szkoły średniej.

Oprócz szkolnictwa wyższego i średniego w Polsce zgodnie $\mathrm{z}$ unormowaniami międzynarodowymi jest możliwe szkolenie członków załóg statków morskich poprzez kursy na odpowiednie poziomy odpowiedzialności. Kursy te mogą być organizowane przez ośrodki szkoleniowe prowadzące działalność gospodarczą, które zostaną uznane przez terenowe organy administracji morskiej.

Podstawową kadrę związaną z bezpośrednim zatrudnieniem na statkach żeglugi śródlądowej stanowią absolwenci Techników Żeglugi Śródlądowej. Pomimo pewnych redukcji tego typu szkół ze względu na regres przewozów i zachodzące zmiany własnościowe aktualnie funkcjonują trzy zespoły szkół średnich, które kształcą kadry dla tego rodzaju żeglugi (Nakło, KędzierzynKoźle, Wrocław). Uzupełnienie stanowią również Technika Morskie w Szczecinie, Gdyni, Kołobrzegu i Świnoujściu pozwalające absolwentom na uzyskanie dyplomów nawigatora morskiego i mechanika okrętowego [1].

\section{System bezpieczeństwa}

Dla całej administracji morskiej stworzony został od podstaw system PHICS (Polish Harbours Information \& Control System), czyli elektroniczna wymiana dokumentów istotnych dla realizacji obowiązków nałożonych na administrację państwa portu i państwa nadbrzeżnego. System zaprojektowany i wykonany przez firmę Grupa Emax zaczął funkcjonować od 11 maja 2004r. Użytkownikiem systemu jest Ministerstwo Gospodarki Morskiej, urzędy morskie, SAR a także Służba Celna i Straż Graniczna (rys.5). W Polsce badaniem wypadków morskich zajmują się izby morskie będące instytucjami prawnymi, nie ma natomiast instytucji, która zajmowałaby się monitorowaniem i analizą wypadków morskich $\mathrm{w}$ aspekcie bezpieczeństwa żeglugi.

W strukturach Urzędu Morskiego w Szczecinie i Urzędu Morskiego w Gdyni funkcjonują systemy kontroli ruchu statków (VTS), a w Urzędzie Morskim w Słupsku Centrum Dyspozycyjno - Kontrolne Administracji Morskiej, które umiejscowione jest w Ustce.

Dla realizacji zadań poszukiwania i ratowania życia na morzu Służba SAR dysponuje specjalistycznymi statkami ratowniczymi oraz brzegowymi stacjami ratowniczymi wyposażonymi w samochody terenowe i szybkie łodzie ratownicze. 


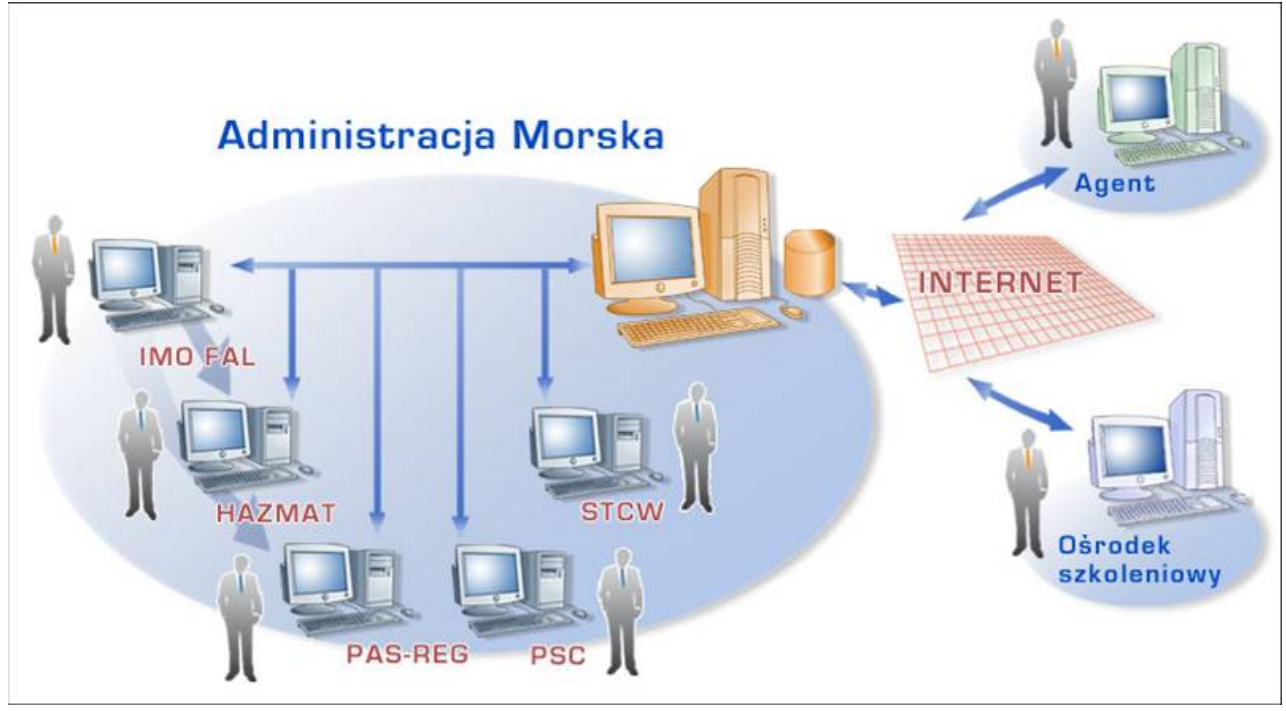

Rys. 5. Logical flow-chart of PHICS system

W ramach poprawy nadzoru nad bezpieczeństwem żeglugi planowane jest utworzenie Krajowego System Bezpieczeństwa Morskiego (KSBM). System ten jest budowany na bazie istniejącej infrastruktury poddanej w dużym zakresie modernizacji. Podstawowym celem budowy systemu jest poprawa bezpieczeństwa żeglugi morskiej oraz przeciwdziałanie skażeniom środowiska morskiego w obszarach morskich Rzeczypospolitej Polskiej. Główne zadania systemu KSBM sprowadzają się do stworzenia i utrzymania warunków niezbędnych dla bezpiecznej i efektywnej działalności ludzkiej w obszarach morskich RP oraz kontrolowania czy żegluga lub inna działalność na morzu wykonywana jest zgodnie z obowiązującymi przepisami prawa polskiego i umowami międzynarodowymi [1].

\section{Podsumowanie}

Bezpieczeństwo transportu morskiego charakteryzuje się swoją specyfiką. Na polskich obszarach morskich ruch statków poza strefami podejściowymi do portów odbywa się w sposób nieskoordynowany. Duże znaczenie w zakresie ratowania życia i skutków ewentualnych katastrof morskich ma ruch tranzytowy na morzu otwartym. Natomiast drogi wodne śródlądowe są bardzo słabo wykorzystywane do funkcji transportowych. 
Wypadki morskie zdarzają się stosunkowo rzadko, jakkolwiek każda duża katastrofa morska może mieć fatalne skutki dla systemu ekologicznego Morza Bałtyckiego. W wypadkach morskich duże znaczenie odgrywa czynnik ludzki. Szkolenie kadr morskich jest w Polsce rozwiązane systemowo dobrze, jakkolwiek paradoksalnie na bezpieczeństwo transportu morskiego na polskich obszarach morskich w dużym zakresie wpływ mają kadry szkolone w innych, czasami odległych zakątkach świata.

Obecnie wprowadzane rozwiązania techniczne umożliwiają zarządzenie bezpieczeństwem na rozległych obszarach wodnych. W Polsce podejmowane są próby budowy takich systemów, których głównym celem jest poprawa bezpieczeństwa żeglugi morskiej oraz przeciwdziałanie skażeniom środowiska morskiego w obszarach morskich Rzeczypospolitej Polskiej.

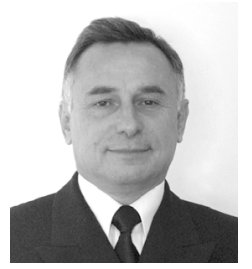

Ph.D. Master Mariner HAJDUK Jerzy, professor, Maritime University of Szczecin, speciality: marine traffic engineering and vessel safety. Numerous publications concerning the application of research results on vessel traffic in restricted water areas for designing fairways, port basins and other hydrotechnical constructions. 
